\title{
Ku pełnej integracji - dostępność edukacji wyższej dla osób niepełnosprawnych
}

\section{Wstęp}

Wiek XIX wraz z ukształtowaniem się kapitalizmu przyniósł w Europie zasadniczą zmianę położenia społecznego osób niepełnosprawnych. Zdaniem Michaela Oliviera w tym okresie doszło do skonstruowania takiego postrzegania niepełnosprawności, które spowodowało marginalizację i wykluczenie tej kategorii społecznej. Wyrastało ono z dominacji w tym okresie ideologii indywidualizmu oraz procesów związanych ze wzrostem znaczenia medycyny w nowoczesnych społeczeństwach i narzuconym przez nie wzorem normalności ${ }^{1}$. W wyniku tego doszło do powstania definicji niepełnosprawności, które umieszczały jej istotę w indywidualnym niedostosowaniu do życia w społeczeństwie jednostek i traktowały ją jak problem o charakterze medycznym ${ }^{2}$. Zaangażowanie medycyny w rozwiązywanie problemów społecznych spowodowało wzrost znaczenia procedur medycznych w odniesieniu do kwestii związanych z niepełnosprawnością. W rezultacie medycyna stała się ważnym narzędziem kontroli społecznej ${ }^{3}$. Ugruntowała bowiem

1 M. Olivier, The politics of disablement: a sociological approach, London 1990, s. 58.

2 D. Goodley, Disability studies. An interdisciplinary introduction, London 2011, s. 6-7.

3 P. Abberley, The concept of oppression and the development of a social theory of disability, [w:] Overcoming disabling barriers, ed. L. Barton, London-New York 2006, s. 17. 
64 postrzeganie niepełnosprawności jako osobistej tragedii ${ }^{4}$. Wyraźnie precyzując rolę osób niepełnosprawnych jako pacjentów, którzy nie ponoszą co prawda odpowiedzialności za swoje dysfunkcje, jednak muszą dążyć do jak najszybszego wyleczenia, podejmując współpracę z profesjonalistami zdolnymi im to zapewnićs .

W wyniku tych procesów powstał cały zinstytucjonalizowany system opieki nad osobami niepełnosprawnymi, który obejmował przytułki, szpitale, szkoły. W XIX wieku większość dzieci niepełnosprawnych uczyła się w szkołach specjalnych, najczęściej połączonych z internatami ${ }^{6}$. Stanowiły one przestrzeń całkowitego wyłączenia z normalnego życia społecznego, dzieci funkcjonowały w zamkniętych, specjalnych instytucjach przez cały okres swojej edukacji, nie mając w tym czasie możliwości nawiązania normalnych relacji społecznych i kontaktów ze sprawnymi rówieśnikami ${ }^{7}$. Osoby realizujące ten model nauki nie były wspomagane w kierunku osiągnięcia prawdziwej niezależności, raczej były odizolowane od świata zewnętrznego ze względu na swoje deficyty zmysłowe, psychiczne lub fizyczne ${ }^{8}$. Instytucje te wzmacniały wykluczenie osób niepełnosprawnych ze społeczeństwa ${ }^{9}$. Segregacja i izolacja nie tylko przyczyniały się do kształtowania się w tym czasie negatywnych postaw społecznych wobec osób niepełnosprawnych, lecz także budowały wśród samych niepełnosprawnych przekonanie o własnej niesamodzielności i niemożności udziału w wielu przestrzeniach życia ze względu na deficyty fizyczne, zmysłowe lub psychiczne ${ }^{10}$. System edukacji specjalnej stanowił w tym ujęciu wyraz oczekiwań społecznych w stosunku do tej kategorii społecznej, przewidujących jej ograniczony udział w życiu społecznym ${ }^{11}$. Wykluczało to budowanie strategii afirmacyjnych, pozwalających na konstruowanie pozytywnych wizerunków niepełnosprawności wśród tej kategorii społecznej ${ }^{12}$.

4 C. Barnes, G. Mercer, Niepełnosprawność, przeł. P. Morawski, Warszawa 2008, s. 38.

5 T. Parsons, Struktura społeczna a osobowość, tłum. M. Tabin, Warszawa 1969, s. 231-240.

6 C. Barnes, G. Mercer, Niepełnosprawność, dz. cyt., s. 38.

7 D. D. Smith, Special education: Teaching in an age of opportunity, Boston 2001, s. 15.

8 W. V. Bryan, In search of freedom: How persons with disabilities have been disenfranchised from the mainstream of American society, Springfield 1996, s. 4.

9 D. Marks, Disability: Controversial debates and psychosocial perspectives, New York 1999, S. 23-24.

10 D. L. Braddock, S. L. Parish, An institutional history of disability, [w:] Handbook of disability studies, ed. G. L. Albrecht, K. D. Seelman, M. Bury, Thousand Oaks CA 2001, s. 53.

11 C. Barnes, G. Mercer, Niepełnosprawność, dz. cyt., s. 39.

12 S. French, J. Swain, Working with disabled people in policy and practice, London 2012, s. 22-23. 
Współcześnie system szkolnictwa nadal stanowi przestrzeń izolacji, wciąż bowiem jeszcze mamy do czynienia z kształceniem osób niepełnosprawnych w ramach szkół specjalnych - osobnych, które uczą dzieci mające określone rodzaje niepełnosprawności w specjalnych warunkach ${ }^{13}$. Takie praktyki przez wiele lat były pozytywnie odbierane przez same środowiska osób niepełnosprawnych, zwłaszcza przez osoby niesłyszące i reprezentujące je organizacje ${ }^{14}$. Jednak mimo uzasadnień, że młodzież kształcona w takich placówkach ma opiekę lepiej dostosowaną do swoich potrzeb, otrzymuje ona relatywnie niższy poziom wykształcenia w stosunku do sprawnych rówieśników zarówno pod kątem kwalifikacji, jak i umiejętności ${ }^{15}$, co w dalszych etapach powoduje trudności w kontynuowaniu kształcenia na poziomie wyższym oraz znalezieniu pracy na otwartym rynku ${ }^{16}$.

W większości współczesnych społeczeństw europejskich pod koniec wieku XX i na początku XXI przyjęto szereg rozwiązań legislacyjnych, które opierają się na zasadach równości w odniesieniu do kształcenia osób niepełnosprawnych. Zasada edukacji dla wszystkich, niezależnie od stanu zdrowia i niepełnosprawności, obok zapisów prawnych została jednocześnie połączona z praktykami ułatwiającymi uczestnictwo w niej osobom, które mają ograniczenia zmysłowe, fizyczne i umysłowe, utrudniające uczenie się. Można zauważyć, z dziś w krajach Europy zauważalna jest tendencja do odchodzenia od kształcenia specjalnego w ramach instytucji segregujących na rzecz integracji osób niepełnosprawnych. Skutkuje to upowszechnianiem się w nich modelu edukacji włączającej, oferującej udział w powszechnym kształceniu, co umożliwia pełne włączenie tej kategorii do pełnego udziału w życiu społeczeństwa ${ }^{17}$. Tendencje te zauważalne są również w Polsce: od 2010 roku systematycznie spada liczba uczniów kształconych w specjalnych placówkach edukacyjnych na szczeblu podstawowym (w roku szkolnym 2010/11 w szkołach specjalnych uczyło się 40,28 proc. uczniów niepełnosprawnych, a w roku szkolnym 2013/14 odsetek ten wyniósł 38,71. Zmiany te są jeszcze bardziej widoczne na wyższych szczeblach edukacji - w szkołach średnich kończących się maturą, umożli-

13 Por. K. Geletta, M. Grewiński, Usługi społeczne na rzecz osób niepełnosprawnych - doświadczenia międzynarodowe, Warszawa 2014, s. 27.

14 T. Shakespeare, Disability rights and wrongs, New York-London 2006, s. 87.

15 C. Bartnes, G. Mercer, Niepełnosprawność, dz. cyt., s. 58.

16 I. Christie, G. Mensah-Cocker, An inclusive future? Disability, social chance, opportunities for greater inclusion by 2010, London 1999, s. 89.

17 K. Geletta, M. Grewiński, Usługi społeczne na rzecz osób niepełnosprawnych..., dz. cyt., s. 26. 
66 wiającą podjęcie studiów, w placówkach specjalnych w roku 2013/14 uczyło się 26,55 proc., a w roku szkolnym 2010/11 40,82 proc. $^{18}$. Mimo tych tendencji w Polsce osoby niepełnosprawne są wciąż znacznie gorzej wykształcone niż osoby sprawne. W skali kraju odsetek osób niepełnosprawnych z wyższym poziomem wykształcenia jest stosunkowo niewielki i stanowi on 17 proc., a w przypadku poziomu średniego i policealnego - 32 proc. Liczba osób niepełnosprawnych ze stopniem co najmniej doktora wynosi $13059^{19}$. Jednak, jak pokazują dane spisowe, wzrasta poziom wykształcenia osób niepełnosprawnych w porównaniu z rokiem 2002, wyrażający się wzrostem najwyższego poziomu wykształcenia, tj. podniesieniem się o 4 punkty procentowe odsetka osób z wyższym wykształceniem (z 4 proc. do ok. 8) oraz ze średnim i policealnym - z 21 proc. $w 2002$ roku do 28 proc. w $2011^{20}$.

W związku z tym zasadniczym celem artykułu będzie ukazanie zachodzących dziś zmian związanych z dostępnością kształcenia osób niepełnosprawnych na poziomie wyższym. Odtworzone zostaną one w oparciu o opinie studentów niepełnosprawnych na temat barier i ułatwień w dostępie do edukacji na poziomie wyższym. Pozwoli to na zrekonstruowanie funkcjonujących praktyk oraz rozwiązań w tej dziedzinie i ich recepcji w środowisku osób niepełnosprawnych, do którego są kierowane.

\section{Podejście do edukacji osób niepełnosprawnych w Polsce}

W Polsce w myśl konstytucji obowiązującej od 1997 roku prawo do edukacji przysługuje wszystkim, również uczniom niepełnosprawnym. Istniejące akty prawne regulujące dostęp do szkolnictwa zarówno średniego, jak i zawodowego oraz wyższego nastawione są na edukację o charakterze włączającym ${ }^{21}$. Wpisują się one w społeczny model niepełnosprawności, który umieszcza jej istotę w charakterze relacji pomiędzy osobą niepełnosprawną a otoczeniem społecznym, koncentrując się nie na biologicznych

18 Por. Raport GUS, Oświata i wychowanie w roku szkolnym 2013, http://stat.gov.pl/obszarytematyczne/edukacja/edukacja/oswiata-i-wychowanie-w-roku-szkolnym-20132014,1,8. html (dostęp: 06.07.2015).

19 Por. Raport GUS, Ludność i gospodarstwa domowe. Stan i struktura społeczno-ekonomiczna, cz. I Ludność, http://www.stat.gov.pl/gus/12773_PLK_HTML.htm. (dostęp: 06.07.2013).

20 Por. Raport GUS, Ludność i gospodarstwa domowe. Stan i struktura społeczno-ekonomiczna, cz. I Ludność, dz. cyt.

21 K. Geletta, M. Grewiński, Usługi społeczne na rzecz osób niepełnosprawnych..., dz. cyt., s. 25. 
dysfunkcjach jednostki, ale na relacji między osobą niepełnosprawną a społeczeństwem, i widząc $\mathrm{w}$ niej problem związany $\mathrm{z}$ istnieniem barier $\mathrm{w}$ otoczeniu fizycznym i społecznym oraz kulturowym, uniemożliwiający pełną integrację osób niepełnosprawnych ${ }^{22}$. Wymaga to spojrzenia na niepełnosprawność przez pryzmat społecznych ograniczeń i powoduje konieczność dostosowania środowiska fizycznego do potrzeb zgłaszanych przez osoby niepełnosprawne, tak by mogły one na równych zasadach z osobami pełnosprawnymi funkcjonować w rzeczywistości społecznej. Ratyfikowanie przez Polskę w 2012 roku Konwencji ONZ o prawach osób niepełnosprawnych wpisuje się w ten model myślenia o niepełnosprawności. Wyznacza nowy kierunek rozwoju myślenia o niepełnosprawności w Polsce. Ma to daleko idące konsekwencje, bowiem przyjęta konwencja, opierając się na poszanowaniu praw człowieka, tworzy podstawę do nowego spojrzenia na problem wykluczenia osób niepełnosprawnych z pełnego udziału w życiu społecznym, który wymaga przebudowania dotychczasowego systemu pomocy społecznej, opierającego się na opiece społecznej i indywidualnej rehabilitacji, na model, który będzie koncentrował się na włączeniu tej kategorii społecznej do społeczeństwa, dzięki zarówno prawu wyrównującemu szanse, jak i likwidacji barier w praktyce życia codziennego ${ }^{23}$. Wymaga to kompleksowych zmian w podejściu do tej kategorii społecznej. Podejście redystrybucyjne, polegające na wypłacaniu świadczeń osobom niepełnosprawnym, które w pewien sposób zostały wykluczone ze społeczeństwa $\mathrm{w}$ procesie orzekania o stopniu ich niepełnosprawności, jest nieefektywne zarówno w wymiarze społecznym - powoduje bowiem marginalizację tego środowiska, jak i jednostkowym, nie pozwalając na usamodzielnienie się osób niepełnosprawnych ${ }^{24}$. Powoduje to wzrost znaczenia polityki nastawionej na aktywizację osób niepełnosprawnych, w której podkreślana jest rola partycypacji w miejsce bezpieczeństwa socjalnego ${ }^{25}$. Jednak aby

22 C. Barnes, Understanding the social model of disability: past, present and future, [w:] Routledge handbook of disability studies, ed. N. Watson, A. Roulstone, C. Thomas, London-New York 2012, s. 18.

23 V. Finkelstein, Disability: a social challenge or an administrative responsibility?, [w:] Disabling barriers - enabling environments, ed. J. Swain i in., London 1993, s. 37-38.

24 S. Golinowska, Demedykalizacja niepełnosprawności i jej konsekwencje instytucjonalne, „Polityka Społeczna” 2012, (numer monograficzny Zdrowie, sprawność i aktywność starzejacej się populacji, pod red. S. Golinowskiej), s. 5.

25 M. Rymsza, Rola służb społecznych w upowszechnianiu aktywnej polityki społecznej, [w:] Aktywizacja, partnerstwo, partycypacja - o odpowiedzialnej polityce społecznej, pod red. M. Grewińskiego, J. Tyrowicz, Warszawa 2007, s. 14. 
68 pełne uczestnictwo w społeczeństwie tej kategorii stało się powszechne, konieczne jest usunięcie barier w wymiarze przestrzennym, kulturowym i społecznym, które stanowią element wykluczający. Dotyczy to zwłaszcza kształcenia, którego poziom odgrywa istotną rolę, jeżeli chodzi o rywalizację i konkurencję na rynku pracy. Stanowi ono obecnie istotny element dający szansę na znalezienie pracy i usamodzielnienie się dla tej kategorii osób. Daje tym samym możliwość niezależnego życia, które pozwoli osobom niepełnosprawnym na samostanowienie o sobie i odejście od funkcjonującego dotąd modelu budowania zależności środowiska osób niepełnosprawnych od społeczeństwa ${ }^{26}$, co w konsekwencji kształtuje postawy bierne wśród osób niepełnosprawnych, nastawione na pobieranie należnych im świadczeń socjalnych i medycznych. Stanowi to główny czynnik uniemożliwiający pełną niezależność tej kategorii społecznej we współczesnych społeczeństwach ${ }^{27}$.

\section{Metoda badawcza}

Przeprowadzono 20 wywiadów z niepełnosprawnymi studentami uczelni krakowskich. Dobór próby miał charakter celowy - zdecydowano się przebadać 5 osób z niepełnosprawnością wzroku, 5 osób z deficytem układu ruchu oraz 5 osób niesłyszących i słabosłyszących oraz 5 osób, które miały inne typy niepełnosprawności (znalazły się tu 2 osoby mające niepełnosprawność sprzężoną, 2 osoby z niepełnosprawnością psychiczną oraz jedna z chorobą metaboliczną). Taki dobór kategorii był uzasadniony funkcjonującymi opracowaniami statystycznymi opracowanymi przez GUS, w których właśnie takie typy niepełnosprawności przyjęto jako podstawę przedstawienia liczby studentów niepełnosprawnych studiujących na uczelniach wyższych ${ }^{28}$. Zróżnicowanie próby pod kątem rodzaju niepełnosprawności miało na celu oddanie pełnego obrazu środowiska oraz możliwości, jakie ono daje. Badanie bez uwzględnienia rodzaju dysfunkcji mogłoby zakłócić wnioskowanie, bowiem każdy rodzaj niepełnosprawności wymaga innego rodzaju dostosowania otoczenia.

26 T. Shakespeare, Disability rights and wrongs, dz. cyt., s. 165.

27 M. Olivier, The politics of disablement...., dz. cyt., s. 93.

28 Por. Raport GUS, Oświata i wychowanie w roku szkolnym 2013/2014, http://stat.gov.pl/ obszary-tematyczne/edukacja/edukacja/oswiata-i-wychowanie-w-roku-szkolnym013 2014,1,8.html (dostęp: 08.07.2015). 
Pytania badawcze:

1. Jakie bariery w środowisku oceniane są jako utrudniające kształcenie na poziomie wyższym?

2. Zastosowanie jakich rozwiązań ułatwia studiowanie?

3. Na ile zastosowanie nowoczesnych technologii w procesie studiowania ułatwia osobom niepełnosprawnym dostęp do edukacji na poziomie wyższym?

Wywiad miał charakter swobodny opierał się na przewodniku, który miał modułową budowę. Pierwsza część obejmowała pytania o charakterze wprowadzającym, dotyczące przebiegu dotychczasowej kariery szkolnej, zwłaszcza jej rodzaju oraz motywacji podjęcia studiów na wybranym kierunku. Druga część obejmowała pytania dotyczące napotykanych barier i sposobów ich pokonywania przez osoby niepełnosprawne w toku całego procesu kształcenia, a zwłaszcza podczas studiów. Pytano tu też o rolę nowych technologii informatycznych i komunikacyjnych i ich wpływ na jakość procesu kształcenia na poziomie wyższym. Ostatnia część wywiadu poświęcona była odtworzeniu rozwiązań, które ułatwiają studentom niepełnosprawnym dostęp do kształcenia na poziomie wyższym. W tej części zadawano pytania o udogodnienia, z jakich korzystają respondenci w trakcie studiów, oraz o źródła informacji na temat możliwości skorzystania z nich.

\section{Studia wyższe przestrzenią integracji}

Celowo dobrana próba badawcza poddana badaniu była zróżnicowana pod kątem wybranego rodzaju studiów - miało to na celu wskazanie zależności pomiędzy kierunkiem i trybem studiów a ich dostosowaniem do możliwości studentów. 9 osób kształciło się na profilach o charakterze humanistycznym, 4 - pedagogicznym, 5 - technicznym, 2 - ekonomicznym. Zdecydowana większość badanych studentów wybierała stacjonarny tryb kształcenia tylko 5 osób spośród badanych zdecydowało się na niestacjonarne studia. Uzasadniali to przede wszystkim trudnościami wynikającymi z barier architektonicznych i niemożliwości ich codziennego pokonywania (były to osoby w dużym stopniu zależne od innych).

Większość respondentów wybierała też uczelnie państwowe - tylko 2 osoby studiowały na uczelniach niepublicznych. Wybór ten nie tyle był podyktowany większą dostępnością tych uczelni dla osób niepełnosprawnych, 
70 ile wynikał z zainteresowań samych respondentów i ich chęci studiowania na określonym kierunku.

Połowa badanych (10 osób) do czasu studiów nie korzystała z otwartej oferty edukacyjnej - na poziomie podstawowym, gimnazjalnym i średnim kształciło się w ośrodkach specjalnych dostosowanych do potrzeb osób z daną niepełnosprawnością lub w szkołach o charakterze integracyjnym. Tak więc, jak pokazują wywiady, studia wyższe były dla większości momentem wejścia w szerokie środowisko społeczne, które nie miało charakteru dostosowanego do określonego stopnia i typu niepełnosprawności, bowiem na tym stopniu edukacji nie jest możliwe tworzenie szkół o charakterze integracyjnym, nastawionych i przygotowanych na przyjmowanie osób niepełnosprawnych. Stanowiło to duże wyzwanie dla większości badanych i przed rozpoczęciem studiów było źródłem wielu obaw. Respondenci ci mieli początkowo duże trudności w odnalezieniu się w nowej dla nich rzeczywistości. Z perspektywy czasu oceniali, że kształcenie specjalne i integracyjne nie przygotowało ich do pełnego udziału w społeczeństwie. $\mathrm{Na}$ wcześniejszych etapach edukacji funkcjonowali w środowisku, które było nastawione na zapewnienie im odpowiednich środków dydaktycznych oraz specjalistycznych narzędzi umożliwiających kształcenie. W nowych warunkach musieli samodzielnie się o nie zatroszczyć. Respondenci podkreślali, że na początku największą trudność sprawiała im właśnie ta konieczność ciągłego zabiegania o narzędzia, które zapewniłyby im możliwość kształcenia się. Obrazują to słowa jednego z badanych:

No przyznam, że nie jest bardzo prosto sobie poradzić, na wyższym szczeblu - szczególnie. Szkoła podstawowa i średnia była dostosowana do moich potrzeb, więc i Braille był na porządku dziennym, i różne pomoce były dostosowywane, tak żeby osoby niewidome mogły dotknąć. Na przykład na matematyce różne figury, które tam można było dotknąć. Natomiast już na uczelni wyższej to tak naprawdę ile udało się mi wywalczyć, to tyle miałam (wywiad IV).

Zdecydowanie inne doświadczenia prezentują osoby, które od początku kształciły się w otwartych placówkach edukacyjnych. Studia stanowiły dla nich przedłużenie dotychczasowej edukacji i nie czuli się zagubieni w warunkach, gdzie o wszystko, co potrzebne im do studiowania, musieli starać się sami. Od początku swojej kariery edukacyjnej przełamywali bariery, zarówno architektoniczne, jak i związane z koniecznością specjalnego dostosowania 
dla siebie narzędzi ułatwiających kształcenie. $Z$ tego powodu znacznie szybciej i łatwiej adaptowali się do otaczającego ich środowiska. Nie oczekiwali, że otoczenie będzie im na tyle przyjazne, by wyeliminować niedogodności i problemy, które są związane z ich niepełnosprawnością. Wykazywali się swoistym heroizmem, podkreślając, że to nie otoczenie ma się dostosować do nich, ale oni do niego. Taką postawę obrazują słowa:

Na wyższej uczelni nie ma już utrudnień. Tylko trzeba pójść gdzieś, gdzie jest winda. Ja się może źle na to patrzę, bo staram się nigdy nie biadolić, przyzwyczaiłem się, że tak po prostu jest. Jak widzę schody, to zawsze myślę, że to nie jest niczyja wina, i szukam windy, jak jej nie ma, to koledzy zawsze pomogą (wywiad III).

Analizując przeprowadzone wywiady, można zauważyć, że badani studenci, gdy znaleźli się na otwartym rynku edukacyjnym i muszą funkcjonować na nim na normalnych warunkach rywalizacji i konkurencji, przyjmują postawy aktywne. Niezależnie od przebiegu kariery szkolnej na poziomie podstawowym i średnim potrafią się zaadaptować do środowiska, które nie ma charakteru w pełni dostosowanego do ich specyficznych możliwości. Mimo ograniczeń fizycznych lub zmysłowych potrafią funkcjonować w warunkach, które nie tylko nie są dla nich specjalnie stworzone, ale często są dla nich nieprzyjazne. Pokazuje to, że dzięki usuwaniu barier i otworzeniu się społeczeństwa na integrację osób niepełnosprawnych będą oni mogli w pełni uczestniczyć w życiu społecznym na podobnym poziomie jak osoby sprawne. Stwarza to duże szanse dla ergonomii, będącej dziś jedną z podstawowych dziedzin naukowych pozwalających na wypracowanie rozwiązań, które dzięki powszechnemu stosowaniu pozwolą na prawdziwe włączenie tej kategorii do społeczeństwa.

\section{Bariery w dostępie do edukacji wyższej}

Respondenci, pytani o bariery w studiowaniu, najczęściej wskazywali bariery architektoniczne. To one okazywały się najbardziej uciążliwe w podejmowaniu studiów i realizacji procesu kształcenia. $\mathrm{Z}$ wypowiedzi przebijało przekonanie, że powinny pojawić się pewne standardy, które zostaną wprowadzone do projektowania i przekształcania przestrzeni publicznej tak, by była ona dostępna dla osób niepełnosprawnych. Respondenci podkreślali, 
72 że nie chodzi tu wyłącznie o zapisanie pewnych regulacji w uchwałach lub międzynarodowych konwencjach, które zostały przez nasz kraj ratyfikowane. W ich przekonaniu potrzebne są przepisy, które będą miały charakter zbioru praktycznych dyrektyw, a ich wykonanie będzie kontrolowane na poziomie gmin. Zdaniem badanych pozwoliłoby to na większa aktywność osób niepełnosprawnych i naprawdę przyczyniło do ich obecności w życiu społecznym, bowiem nie czuliby obaw wobec istniejących dziś wciąż barier. Jeden $\mathrm{z}$ respondentów wprost powiedział:

To jest najważniejsze raczej, żeby wszystko było po prostu dostępne dla wszystkich: i sprawnych, i niepełnosprawnych, bez podziałów (wywiad VI).

Teraz w przekonaniu badanych najgorszy jest brak pewności, czy obiekty, nawet te określane jako dostępne, są takie naprawdę. Najczęściej mówiono o tym, że przygotowane podjazdy czy poręcze były niefunkcjonalne dla tej kategorii osób. Były zbyt strome, umieszczone za wysoko lub za nisko. Wynikało to $\mathrm{w}$ ich przekonaniu $\mathrm{z}$ dostosowywania i korygowania otoczenia społecznego nieco na siłę, tak by wykazać, że ma się infrastrukturę czyniącą dany obiekt dostępnym dla niepełnosprawnych. Tymczasem, jak mówili respondenci, zwykle lepiej wiedzieć, że obiekt jest niedostępny, i zabezpieczyć się przed tym wcześniej, niż nagle nie móc skorzystać z podjazdów, bo są zbyt strome, albo nie przecisnąć się przez za wąskie drzwi wejściowe.

Respondenci wskazywali konkretne rozwiązania ułatwiające im funkcjonowanie w środowisku społecznym, jednak zwracali uwagę, że dostosowanie powinno być $\mathrm{w}$ większej mierze strategicznym celem niż tylko działaniami doraźnymi, które pozwalają adaptować istniejące obiekty, czyniąc je dostępnymi dla osób niepełnosprawnych. Bo choć to istotny kierunek, to jednak polityka władz samorządowych powinna być nastawiona na to, by realizować długofalowe działania mające na celu wypracowanie uniwersalnych zasad budowania przestrzeni publicznej tak, aby była ona przyjazna dla wszystkich, również niepełnosprawnych.

W wypowiedziach podkreślano jednak, że dostępność obiektów na uczelniach wyższych - przynamniej w Krakowie - jest stosunkowo duża, a otoczenie staje się coraz bardziej przyjazne. Mówiono o szerokich chodnikach, obniżonych zjazdach na ulicę, windach, podnośnikach oraz podjazdach umożliwiających samodzielne funkcjonowanie. Jedna z respondentek, oceniając bariery, z jakim boryka się na co dzień, studiując, powiedziała: 
Wszystko jest na uczelni. Mam nawet pokój taki naprawdę przystosowany, tylko że niektóre rzeczy są dla osób, które mają sprawne ręce. Ja nie mam sprawnych rąk, więc przydałoby się ulepszyć parę rzeczy, ale i tak jest dobrze (wywiad XII).

Osoby niepełnosprawne podkreślały, że nie chodzi o tworzenie specjalnych miejsc dostępnych właśnie dla nich, ale o pełen udział w społeczeństwie i korzystanie z tych samych możliwości, które mają osoby sprawne, zwłaszcza w odniesieniu do kształcenia. Wielu badanych mówiło, że wybór szkoły na wcześniejszych etapach był podyktowany jej dostępnością, nie zainteresowaniami, nie proponowanym profilem, tylko istnieniem w placówce udogodnień dla osób niepełnosprawnych. W ich przekonaniu to nie pozwala na mówienie o pełnym włączeniu tej kategorii społecznej do społeczeństwa, bowiem zwykle osoby niepełnosprawne stają w sytuacji, w której mają ograniczony wybór w porównaniu ze sprawnymi rówieśnikami. Podobnie w ocenie respondentów wygląda kwestia kształcenia na poziomie wyższym: zwracają oni uwagę, że są kierunki, które są powszechnie postrzegane jako odpowiednie dla tego środowiska, bowiem dają szansę na pracę, która będzie zgodna z możliwościami fizycznymi osób niepełnosprawnych.

Wskazuje to na obecne w świadomości społecznej przekonanie o niemożności dostosowania środowiska pracy i otoczenia do możliwości osób niepełnosprawnych, traktowane są one jako determinujące wybór kierunku kształcenia i przyszłego zawodu przez osoby niepełnosprawne. W rezultacie jest to mechanizm wykluczający tę kategorię osób, gdyż przez bariery tkwiące w stereotypowych wyobrażeniach na temat możliwości fizycznych osób niepełnosprawnych uniemożliwia się im podjęcie zgodnego z zainteresowaniami kierunku studiów. Obrazują to słowa jednego ze studentów:

Jak przyjmowałem się na studia z geologii, więc jasną rzeczą jest to, że dużo zajęć jest w terenie praktycznych, tak, w kamieniołomach, w kopalniach i przeróżnych odsłonięciach. Więc kiedy ja się np. przyjmowałem na studia, miałem ogromny problem z komisją rekrutacyjną, tak. Oni za wszelką cenę chcieli mnie przekonać, że to nie jest dobry wybór dla mnie. Okazało się, że kończę te studia, tak, i jakoś się udało, mimo takich wielkich kłód rzucanych pod nogi (wywiad XV).

Takie nastawienie w pewnym sensie wyrasta z różnic, które można zauważyć w kwestii dostosowania otoczenia do możliwości osób niepełnosprawnych 
74 ze względu na studiowany kierunek. Jest to znacznie trudniejsze na studiach technicznych niż humanistycznych, zauważają to sami badani. Jednak zniechęcanie osób niepełnosprawnych już na etapie rekrutacji stanowi praktykę dyskryminacyjną i nie może być uzasadnione obawą, że będzie jej ciężej studiować ze względu na ograniczenia. Na tym etapie olbrzymie znaczenie będzie miało wykorzystanie dorobku teoretyczno-praktycznego ergonomii, tak by otoczenie stało się przyjazne przyszłym studentom, by mogli w pełni korzystać ze swoich praw do wyboru kierunku studiów zgodnych z ich zainteresowaniami oraz poziomem nabytych wcześniej wiedzy i umiejętności.

Jednak jak zauważają sami badani, jeśli ktoś nie ma dość samozaparcia, żeby wciąż mierzyć się z barierami i czekać, aż zostaną usunięte, powinien wybrać kierunek dający pewność dostępności treści i oferty programowej. W opinii badanych z taką sytuacją mamy do czynienia na kierunkach o charakterze humanistycznym. Respondenci studiujący na nich zgłaszali najmniej problemów w dostępie do wymaganych treści czy książek.

Ułatwienia, na które najczęściej wskazywali badani, były dostępne na uczelni. Stanowiły je specjalistyczne urządzenia pozwalające na skanowanie książek do takiej formy, która byłaby dla nich dostępna. Różnego rodzaju narzędzia technologiczne ułatwiające studiowanie, pozwalające na sprawną komunikację, a przez to podnoszące też jakość życia osób niepełnosprawnych i dające szanse na takie zaadaptowanie się do środowiska, które gwarantuje pełne w nim uczestnictwo, na równych warunkach z osobami sprawnymi. Pozwala też na znaczną samodzielność w procesie studiowania i uniezależnia od pomocy i uprzejmości otoczenia. Jak mówiła jedna z badanych:

Mi niesamowicie pomógł komputer właśnie, który do mnie mówił, na którym mogłam pisać samodzielnie, drukować pracę czy zeskanować książki i czytać dzięki syntezie mowy. Albo właśnie internet, w którym mogłam sobie wyszukać szybką informację i teksty potrzebne na następne ćwiczenia (wywiad XV).

Respondenci często przyznawali, że znaczną część wyposażenia, którego używają, uzyskali w ramach istniejących programów, realizowanych przez instytucje rządowe i pozarządowe. Najczęściej starali się o nie z własnej inicjatywy, składając wymagane wnioski. Nie mieli systemowo zapewnionych specjalnych warunków do studiowania tylko dlatego, że są niepełnosprawni, i w znacznej mierze własnymi siłami dopasowali swoje otoczenie do swoich możliwości, nie oczekując, że ktoś z zewnątrz zrobi to za nich. Pozytywnie 
oceniali oni system wsparcia, który funkcjonował na uczelni w zakresie

pomocy przy usuwaniu trudności organizacyjnych w procesie studiowania. Doceniali zwłaszcza to, że są traktowani indywidualnie, oraz pomoc, która była im oferowana przez działające na uczelniach biura dla osób niepełnosprawnych, dopasowaną do ich specyficznych potrzeb.

Wśród narzędzi najbardziej ułatwiających studiowanie respondenci najczęściej wskazywali olbrzymie znaczenie stosowania nowych technologii w procesie kształcenia, ale też w adaptowaniu się do środowiska. Wymieniali bardzo dużo ułatwień wprowadzanych przez najnowocześniejsze technologie, np. GPS, który dzięki wprowadzonym głosowo komendom pozwala dotrzeć na miejsce. Aplikacje pozwalające na głosowe wybieranie treści, specjalne nakładki, myszki umożliwiające pisanie osobom z niesprawnymi rękami itp. W opinii badanych urządzenia i dostępne technologie informatyczno-komunikacyjne umożliwiają w pełni studiowanie oraz wykonywanie zadań koniecznych do zaliczenia kursów oferowanych w programach studiów. Studenci kierunków technicznych zauważali jednak, że na uczelniach brakuje określonych pomocy, co utrudnia im studiowanie, jednak wprowadzane nowoczesne technologie pozwalają na zniwelowanie tych braków. Dzięki odpowiednim programom można np. otrzymać opis przestrzenny obiektu, który zastępuje dotykanie go dla pełnego poznania, itp.

Najnowsze technologie informatyczne i komunikacyjne są przez respondentów traktowane jako swoiste narzędzia komunikacyjne, mające pomóc w przystosowaniu się do społeczeństwa i funkcjonowaniu w nim na takich zasadach jak osoby sprawne, a nie mające służyć budowaniu specjalnej przestrzeni tylko dla tej kategorii społecznej. Dzięki wykorzystywanym technologiom ma być możliwe samodzielne życie i podejmowanie indywidualnych decyzji odnośnie do swojej drogi edukacyjnej, wyboru zawodu, pracy, nie w oparciu o ograniczenia, jakie wynikają z określonego rodzaju niepełnosprawności. Szanse, jakie dają nowe technologie, pozwalają uczynić otoczenie przyjaznym dla osób niepełnosprawnych.

Można zauważyć, że osoby, które deklarowały w badaniu bardzo wysoki stopień korzystania z nowoczesnych technologii komunikacyjnych w codziennych praktykach, używały internetu przez większą część swojego czasu wolnego, również do celów związanych ze studiowaniem. Pytani o możliwości, jakie daje kształcenie na odległość, wskazywali na ich duże znaczenie na każdym poziomie edukacyjnym. Deklarowali, że na pewno stanowi szansę na uzyskanie i pogłębianie wiedzy oraz może umożliwiać zdobycie wyższego wykształcenia przez osoby, którym obniżona sprawność 
76 ruchowa lub inny typ niepełnosprawności nie pozwalają na studiowanie w trybie tradycyjnym. Pytani, czy korzystali z takich form edukacji, zaprzeczali. Wskazywali na to, że jednak jest to przestrzeń swoistej izolacji, że tylko w pewnych szczególnych warunkach takie rodzaje zdobywania wiedzy byłyby dla nich atrakcyjne. Wyraźnie zaznaczali, że tylko gwałtowne pogorszenie stanu zdrowia lub stopnia niepełnosprawności czasowo na okres choroby lub rehabilitacji byłoby dla nich odpowiednim powodem do dołączenia e-learningu do tradycyjnych metod studiowania. Jednak uważali, że przesunięcie ciężaru osób niepełnosprawnych $\mathrm{z}$ tradycyjnych form studiowania w kierunku wirtualnych kursów byłoby niekorzystne dla tego środowiska. W opinii respondentów osoby niepełnosprawne dużo czasu spędzają same zamknięte $\mathrm{w}$ domu, a studia wyższe są szansą wyjścia do społeczeństwa. Pozwalają poczuć się częścią społecznego świata. Natomiast stworzenie całościowej oferty szkół wyższych opartej o e-learning i adresowanej do osób niepełnosprawnych w ich przekonaniu byłoby źródłem tworzenia kolejnej odrębnej przestrzeni, tym razem wirtualnej, w której panują specjalne warunki. Respondenci zdecydowanie krytycznie oceniali taką możliwość. Wirtualne uniwersytety nie jawiły się w ich wypowiedziach jako szansa na uzyskanie wyższego wykształcenia, ale raczej jako kolejne pole izolacji.

Jednocześnie badani bardzo doceniali możliwość korzystania z wirtualnych bibliotek, elektronicznego dostępu do baz danych oraz słowników. Często korzystali z portali, z których mogli ściągać książki w PDF-ach. Tych działań nie postrzegali jako wykluczających ze społeczeństwa i ograniczających. Zdaniem respondentów stanowiły one duże ułatwienie w procesie studiowania. Podobnie oceniali uczestnictwo w kursach językowych czy korzystanie z korepetycji za pomocą komunikatorów internetowych.

\section{Wnioski}

Przeprowadzone wywiady wyraźnie wskazują, że studenci niepełnosprawni prezentują postawy aktywne. Sami są zaangażowani w rozwiązywanie problemów z dostępnością kształcenia na poziomie wyższym. Wykazywali się też chęcią przełamywania barier tkwiących w otoczeniu fizycznym i społecznym, aby podjąć i realizować studia na kierunkach zgodnych z ich zainteresowaniami, zdolnościami oraz możliwościami. We wszystkich wywiadach pojawiało się przekonanie dotyczące znaczenia edukacji włączającej dla tej kategorii. Zdaniem badanych tworzenie specjalnych szkół, dostosowanych 
do ich specyficznych potrzeb i wymagań, zamiast wyrównywać szanse, raczej pogłębia izolację osób niepełnosprawnych. Zamykają się one w otoczeniu osób mających podobne problemy, a po skończeniu szkoły trudno im się zmierzyć z otaczającą rzeczywistością i podjąć kształcenie na otwartym rynku. Na poziomie wyższym osoby niepełnosprawne muszą rywalizować w warunkach konkurencji. Aby skorzystać z oferty, która jest skierowana do wszystkich, zarówno sprawnych, jak i niepełnosprawnych, muszą wykazać się określonym poziomem wiedzy i umiejętności. Szkoły specjalne nie przygotowują do takiej rywalizacji. Nie pozwalają też na codzienne mierzenie się $\mathrm{z}$ barierami fizycznymi i społecznymi w otoczeniu, bowiem osoby uczące się w nich nie muszą pokonywać codziennie drogi do szkoły, konfrontować się z opiniami społecznymi na swój temat. W związku z tym trudno im się dostosować do istniejących ograniczeń.

Wszyscy badani jednoznacznie pozytywnie oceniali działalność biur osób niepełnosprawnych na uczelniach. W ocenie respondentów okazały się one pomocne przy zapewnieniu indywidualnych pomocy naukowych i oprogramowania, które umożliwiało studiowanie. Znaczna część badanych zwracała uwagę na fakt, że pracują tam osoby, które często są niepełnosprawne, dlatego lepiej rozumieją potrzeby osób niepełnosprawnych i udzielają pomocy. Tak więc mimo samodzielności i aktywności, która cechowała respondentów, potrzebna im była pomoc ze strony instytucji. Ułatwiały one podjęcie i realizowanie procesu studiowania, pomagały, dzięki dostępnym technologiom, wyrównać deficyty osób niepełnosprawnych, tak by mogły studiować na równi z osobami sprawnymi.

\section{Towards full integration - the availability of higher education for people with disabilities}

The primary purpose of the presentation is to show the role and importance in today's society the importance of higher education for the full inclusion of people with disabilities into society. Changing the definition of disability today a large role ascribed cultural barriers to social and physical, which prevent the full operation of this category in society. The basis for the exclusion is not in the light of these concepts inherent deficit alone units, but the oppressive society and the environment, which precludes their full participation in society. An important element that strengthens the social marginalization of this category is access to higher education. Today, because it is a factor increasing the chances of finding a satisfactory future employment in the open labour market. The space of higher education which, because of its nature 
78 is open nature and cannot be separated special, isolated space for people with disabilities within it, which is adapted to their special needs. Therefore, a higher education institutions themselves must be open to the categories of students and provide opportunities for them to study. Carried out by interviewing of disabled students, the study was to show what the barriers and constraints affect the ability of the notion of a higher level of education and study.

Keywords: disability, inclusive education, social model, higher education, information technology and media

\section{Ku pełnej integracji - dostępność edukacji wyższej dla osób niepełnosprawnych}

Podstawowym celem wystąpienia jest ukazanie roli i znaczenia w dzisiejszych społeczeństwach znaczenia wykształcenia wyższego dla pełnego włączenia do społeczeństwa osób niepełnosprawnych. Zmieniające się współcześnie definiowanie niepełnosprawności dużą rolę przypisuje barierom kulturowym społecznym i fizycznym, które uniemożliwiają pełne funkcjonowanie tej kategorii w społeczeństwie. Podstawą wykluczenia nie jest w świetle tych koncepcji sam deficyt tkwiący w jednostkach, ale opresyjne społeczeństwo i otoczenie, które wyklucza ich pełen udział w społeczeństwie. Ważnym elementem, który wzmacnia marginalizację tej kategorii społecznej jest dostęp do wykształcenia wyższego. Współcześnie stanowi ono bowiem czynnik zwiększający szansę znalezienia w przyszłości satysfakcjonującego zatrudnienia na otwartym rynku pracy. Przestrzeń szkolnictwa wyższego, które ze względu na swój charakter ma otwarty charakter i nie można wydzielić specjalnej, wyizolowanej przestrzeni dla osób niepełnosprawnych w jego ramach, która byłaby dostosowana do ich specjalnych potrzeb. W związku z tym to uczelnie wyższe, same musza otworzyć się na tą kategorie studentów i stworzyć możliwości dla ich studiowania.

Przeprowadzone, za pomocą wywiadu wśród niepełnosprawnych studentów, badania miały pokazać, jakie bariery i ograniczenia wpływają na proces pojęcia kształcenia na wyższym poziomie oraz studiowania.

Słowa kluczowe: niepełnosprawność, edukacja włączająca, model socjalny, edukacja wyższa, technologia informacyjna i media

\section{Bibliografia}

Abberley P., The concept of oppression and the development of a social theory of disability, [w: Overcoming disabling barriers, ed. L. Barton, London-New York 2006, s. 21-36. Barnes C., Mecer G., Niepełnosprawność, przeł. P. Morawski, Warszawa 2008. 
Barnes C., Understanding the social model of disability: past, present and future, [w:] Routledge Handbook of disability studies, ed. N. Watson, A. Roulstone, C. Thomas, London-New York 2012.

Braddock D. L., Parish S. L., An institutional history of disability, [w:] Handbook of disability studies, pod red. G. L. Albrecht, K. D. Seelman, M. Bury, Thousand Oaks CA 2001, s. 11-68.

Bryan W. V., In search of freedom: How persons with disabilities have been disenfranchised from the mainstream of American society, Springfield 1996.

Christie I., Mensah-Cocker G., An inclusive future? Disability, social chance, opportunities for greater inclusion by 2010, London 1999.

Finkelstein V., Disability: a social challenge or an administrative responsibility?, [w:] Disabling barriers - enabling environments, ed. J. Swain i in., London 1993, s. 34-43.

French S., Swain J., Working with disabled people in policy and practice, London 2012.

Geletta K., Grewiński M., Usługi społeczne na rzecz osób niepełnosprawnych - doświadczenia międzynarodowe, Warszawa 2014.

Golinowska S., Demedykalizacja niepełnosprawności i jej konsekwencje instytucjonalne, „Polityka Społeczna”, numer monograficzny Zdrowie, sprawność i aktywność starzejącej się populacji, 2012, nr 2, s. 2-6.

Goodley D., Disability studies. An interdisciplinary introduction, London 2011.

Marks D., Disability: controversial debates and psychosocial perspectives, New York 1999.

Olivier M., The politics of disablement: a sociological approach, London 1990.

Parsons T., Struktura społeczna a osobowość, przeł. M. Tabin, Warszawa 1969.

Raport GUS, Ludność i gospodarstwa domowe. Stan i struktura społeczno-ekonomiczna, cz. 1 Ludność, http://www.stat.gov.pl/gus/12773_PLK_HTML.htm (dostęp: 06.07.2015).

Raport GUS, Oświata i wychowanie w roku szkolnym 2013, http://stat.gov.pl/obsza ry-tematyczne/edukacja/edukacja/oswiata-i-wychowanie-w-roku-szkol nym-20132014,1,8.html (dostęp: 06.07.2015).

Raport GUS, Oświata i wychowanie w roku szkolnym 2013/2014, http://stat.gov. pl/obszary-tematyczne/edukacja/edukacja/oswiata-i-wychowanie-w-rokuszkolnym- 0132014,1,8.html (dostęp: 08.07.2015).

Rymsza M., Rola służb społecznych w upowszechnianiu aktywnej polityki społecznej, [w:] Aktywizacja, partnerstwo, partycypacja - o odpowiedzialnej polityce społecznej, pod red. M. Grewińskiego, J. Tyrowicz, Warszawa 2007, s. 13-23.

Shakespeare T., Disability rights and wrongs, New York-London 2006.

Smith D. D., Special education: teaching in an age of opportunity, Boston 2001. 